\title{
Participatory Art as Disaster Education in Bojongsoang District of Bandung Regency
}

\author{
Rahmatsyam Lakoro* Agus Sachari Agung Eko Budiwaspada Setiawan Sabana \\ Faculty of Arts and Design, Institut Teknologi Bandung \\ Ganesha 10, Bandung 40132, Indonesia
}

\begin{abstract}
This research explores the communities around the Bojongsoang district of Bandung Regency that live near Citarum River. The location is disaster-prone area that periodically have to deal with flood and the side effect of it. Disaster mitigation education should be a common knowledge that stored in the inner area and habits to overcome the crisis in the Citarum riverbank area. Participatory art used by strengthening local wisdom related to disaster by involved the community in visual art activity. This research goal is explain using social innovation theory. The qualitative descriptive analysis method on various visual communication media related to speech culture content used in disaster mitigation education media. The current artifacts of communication and design that related to disaster mitigation reviewed and used to develop strategic framework. The results lead to recommendations to design of site specific disaster mitigation educational media.
\end{abstract}

Keywords: model disaster education, local wisdom, mitigation, mural, participatory arts

DOI: $10.7176 / \mathrm{ADS} / 88-01$

Publication date: December $31^{\text {st }} 2020$

\section{Introduction}

Indonesia located in the intersection zone of Eurasian Plate, Pacific Ocean Plate and Indo-Australia causing some areas in Indonesia has the potential to experience disaster periodically. The education to deal with those circumstances has become a necessity in most parts of Indonesia to build resilience to disaster. According to Badan Nasional Penanggulangan Bencana (BNPB/ The National Agency for Disaster Countermeasure), 92\% of disaster in Indonesia recorded from 1815 to 2017 are hydrometeorology disaster. (BNPB, 2019). The disaster affected to infrastructure damage, transportation obstacle in land and sea, insecurity of energy, fluctuation in food production, and declination of economy stability (bnpb.go.id). Citarum is known as a source of living water in West Java, but it is also known as one of the most polluted rivers in the world. Educational media has been developed by utilizing a cultural approach to the speech of local communities such as traditional songs or folk games as an awareness of their living space. Some areas have traditional mitigation patterns and are not always in line with the methods of modern disasters, including communities on the banks of the Citarum River. This study aims to identify, understand and explain the media for disaster mitigation education in areas on the banks of the Citarum River. This research also aims to build an understanding of the concept in designing educational media for disaster mitigation. Educational media for disaster mitigation that has been used to provide understanding to the community has been widely disseminated, both by the government and disaster-related institutions. Some areas in the ring of fire have traditional, vernacular patterns of mitigation that are passed on for generations and are not always in line with modern disaster management (Lakoro et al., 2018). The impact of the study is expected (1) to provide an adequate explanation of disaster education associated with the characteristics of living space of the Indonesian people (2) to encourage the creation of creative approach related to disaster education problems in indigenous Indonesian communities using the potential of Arts and Design; (3) achieving knowledge and technology transfer from universities and R \& D institutions to overcome national problems that related to disaster education; (4) encourage concepts and strategy related to disaster education in product development, innovation and technology that are competitive and sustainable. Cultural variations from one place to another make the approach to planning earthquake handling different in each culture. Those who geographically live in disaster areas generally have plans to deal with disasters that are carried out traditionally. Patterns in a community and social group can influence patterns of assistance. Different cultural groups have different beliefs about the concepts of death and life and often respond to a disaster phenomenon in a way that is not expected by modern people (Ehrenreich, 2001).

\section{Social Innovation}

Social innovations are new solutions to social challenges that have the intent and effect of equality, justice and empowerment (Anderson, Curtis and Wittig, 2014). Social innovation can take forms as ideas, actions, frameworks, models, systems, processes, rules, such as the form of a specific organization. Specifically, there are two closely related concepts in social innovation, either focusing on new social processes or new social impacts and outcomes. The first emphasizes changes in social relations and focuses on efforts to restore the balance of unequal power in the economy in society. Social innovation also means the development and application of new 
ideas about how society should organize interpersonal activities or social interactions to achieve one or more common goals. The researcher seeks to understand how various parties have so far designated disaster education media whose content generally gain awareness about disaster symptoms and how to avoid fatal risks (mitigation). Educational media has a strong impact if synergized with other methods such as disaster simulation or strengthening community capacity to deal with emergencies. Effective strategies for disaster education are expected to come from the unique geographical conditions of Indonesia according to the characteristics of the disaster that faced by communities in disaster-prone areas with existing local wisdom. From the preliminary data in the previous study, information was obtained that the existing media only responded to seasonal cycles of disasters, so that life skills in facing disasters were more widely disseminated through certain families or community systems through cultural perspectives. The ineffectiveness of disaster education media is related to aesthetic aspects in visual communication that make educative messages less understanding, or interesting for people living in disaster areas. These aspects will be related socio-geographically and produce the message as specific as possible. The people of the Nias Islands and Simeleue Island have different ways. With the scale of the disaster and the time that almost coincided with the 2004 tsunami in the western part of the island of Sumatra, around 230,000 tsunami victims in Aceh were too large compared to 6 people who were victims of Simeleue Island. People who live near the sea find the sea water suddenly recedes and immediately reads it as an early symptom of smong which means tsunami in Simeleue's community language. It is they who immediately warn other citizens to move away from the coast and reach high ground. Awareness of the living space of those who are vulnerable to tsunami encourages some indigenous leaders to initiate their own disaster mitigation education through speech culture. One of them was packed in the form of poems by Moh. Riswan R, traditional leader of Simeulue tribe. The poem was composed since Simeleue Island was hit by a tsunami in 1907 and claimed many lives (Karokaro, 2014). In the period 1907-2004, disaster mitigation education was instilled in residents to be able to have knowledge stored in their inner regions and habits in facing crises such as tsunamis. According to (James W. Chesebro, 1996), the essential nature of orality and music to render assessment and judgement. It wasn't only about cognitive process of knowing but involving all senses and pushes to the right action in emergency situation. Environmental communication is inspired by General System Theory which states that living systems carry three important functions namely (1) exchange of matter with the environment and with other living systems; (2) energy exchange with the environment and other living systems; and (3) exchange of formations with their environment and other living systems (G. Flor, Alexander, 2018). Environmental ethics we do not just offset the rights and obligations to the environment, but also limit our behavior and efforts to control various activities so that they remain within the limits of our environmental resilience (Anies, 2017)

\section{Method}

The paradigm in design as research, that the feasibility of testing and reproduction in design research is not more important than its sensitivity to the social context and cultural moments that make the results of the design research resonate with the public or market (Lunenfeld, 2003). Human-centered design research can strengthen the ability of designers to form popular culture and subtly transmit values through design. This is important for designers who want to show their good side in transforming consciousness from conditioned responses to active participation. This research is creating opportunities in optimizing disaster and mitigation educational media design. The opportunities creates by exploring the utilization of local wisdom elements in past mitigation education from the samples on the site.

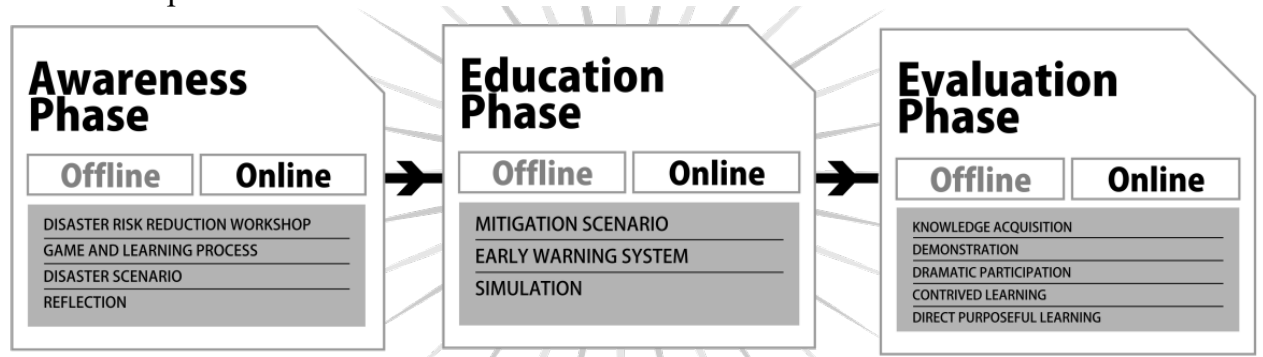

Figure 1. This research methodology conducts to categorize the educational media that enable designer to build concept of educational media for disaster (Lakoro, Rahmatsyam \& Sabana, 2017)

The elements consist of aesthetic aspect, content aspect and technological aspect. The research focus is set to give direction to the research stages according to the given timeframe, among others: (1) Period and Media Edition: this research studied the mural in the Bojongsoang side of Citarum River with time periods from 2018 to 2019. One of the most important issues in disaster management is disaster communication. The murals create space for producing educational message for disaster mitigation; (2) Material / object: objects studied are all forms of murals media related to disaster mitigation. It is also taking into account the aspects of design, communication and level revealed in the visual culture that influence the media. The general form of media that 
used for disaster education in this research are murals. The disaster subjects studied and developed in this research are hydrometeorology disasters; (3) Research area: the study area was taken as a sample in the path of a ring region of fire with different disaster characteristics. The observation and interview conducts specifically in Bojongsoang District, Bandung Regency. It is expected to give an overview of how the participatory art used as educational approaches to its audience, as well as its ability to articulate local wisdom; (4) Subject: the subjects studied were among the audience targeted by disaster education during this time ranging from elementary education to high school education by assumption that in this age the audience does not yet have exposed by disaster education. Other subjects were interviews and focus group discussions with disaster mitigation activists to obtain an overview of concepts that have been, are and will be developed related to disaster mitigation education; (5) Outputs: this research seeks to understand various aspects of disaster mitigation education, so it is specifically expected to produce theories related to communication in the art participatory project.

\section{Results}

The research found that the utilization of local wisdom elements in past mitigation education from the sample of sites should start from the values that already have been exposed to the communities. In 2003, Masyarakat Peduli Sumber Air (MPSA/ Community of Water Resource Care) held campaign of topographic-based land arrangement by using local wisdom of Sundanese people: gunung kaian, gawir awian, lebak caian, legok balongan (mountain forestation, rock plantation with bamboo, keep the water in reclining soil, watering the pond). The campaign found effective since deforestation at Cisanti, the community built 1,847 ponds and provide water. This local wisdom could be revitalizing in contemporary problem and context. Local Bandung graphic artists initiate participatory art movement in Bojongsoang, which is one of Citarum riverbank.

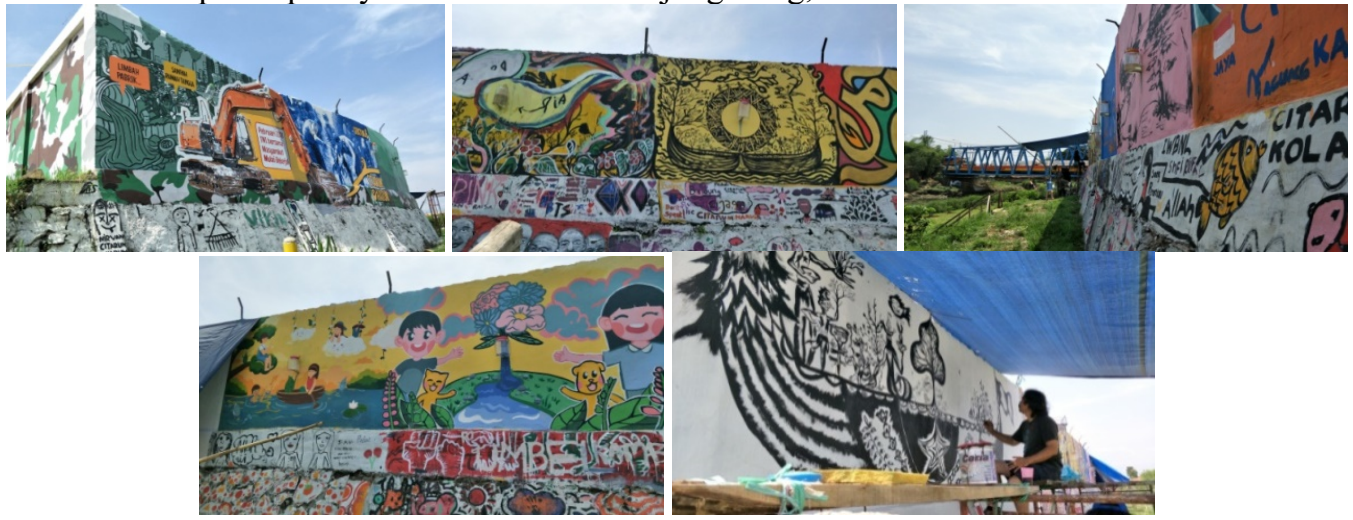

Figure 2. Mural in Bojongsoang next to Citarum riverbank that practice participatory art by Tisna Sanjaya with community around the river, army forces, government, students combined. The results leverage into public awareness of Citarum river's crisis

According to participant artist, the location of this activity was picked carefully because its proximity with the western area of Bandung that plotted as industrial region. The place is also near the junction of Citarum River and Cikapundung River, smaller river that went to Bandung downtown. This activity goal is to nurturing back the river culture that fade away by modernism and practical lifestyle. As one of the most polluted river in the world, it is an approach to embrace the community near Citarum riverbank to sense the crisis by involved them into cultural movement. In the interview conducted with students from Tarumajaya, a village near to Cisanti Lake to explore their awareness of disaster potential in their life-space. It is found that they have not been exposed by disaster education and mitigation. Furthermore, the school and educator usually perceive disaster as something that has to be and it happen naturally.
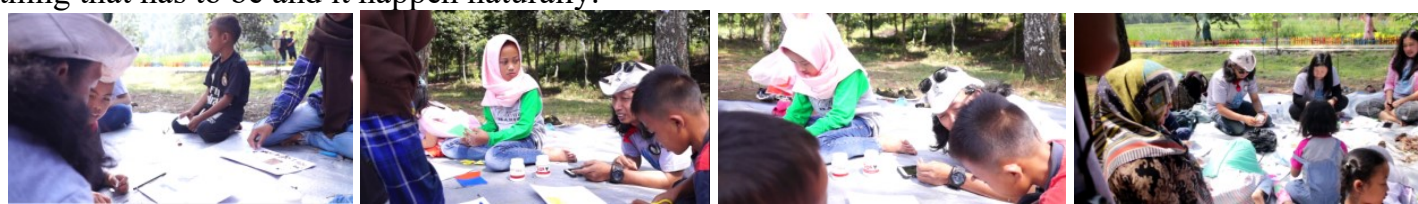

Figure 3. interview with students that live around Cisanti Lake

\section{Discussion}

Art activities' using participatory methods does not directly build the awareness about disaster potential. The knowledge of disaster could manage as a comprehensive curriculum that could be implemented gradually, but the attitude of facing disaster will develop in social field. Participatory activity that involved them could be used to introduce several kind of disaster, how to deal with it and take the right action. The fact is none of the participants ever heard about local wisdom related to their spoken culture of nature conservation. The samples of 
educational media for disaster mitigation demonstrate the using of informative design, but it is not shows the strategic design to create awareness. It also does not show enough literacy in the audience according to disaster mitigation. Participatory art creation provides various educational media using various approaches that enable to deliver message and information effectively. The content of disaster education founded in the samples deliver the message of disaster using the first person view. Media is one aspect that needs to be considered in the dissemination of knowledge to provide education related to disaster. Utilization of Information and Communication Technology provides opportunities to spread massively and simultaneously. Some alternatives are also made by institutions dealing with disaster crises for education efforts for people living in earthquakeprone areas can be started early. Educational tools design concept aim to deliver the contents through the media that build knowledge and at the same time, entertain the user. The common media using physical platform like information graphic panel at the museum, but also create the possibility to use virtual content for specific devices, or environmental graphic that site-specific such as mural arts.

\section{Conclusion}

The involvement in participatory art methods would be more interesting because the audiences are setting up to get involve with art making process. Education with art activities is able to deliver almost every possibility of educational contents in various vernacular art and design approach. The content also describe the recovery process and how the people resilience with disaster. It is important to strategize the messages. Local wisdom found in Citarum River, or Sundanese people in general, holds messages about mitigation, preservation and the sustainability of life with nature, ie: in the proverb "leuweung ruksak, cai beak, manusa balangsak" (damaged forests, depleted water, miserable humans). The research found that the utilization of local wisdom using oral culture elements in past mitigation education from the sample of sites should start from the values that already have been exposed to the communities. Disaster brings the uncomfortable memory, but the development of idioms that related to the culture of audience will help the acceptance of information. The information not only adding knowledge in the audience's cognitive, but also enrich their emotional experiences. As the communication reach the affective level, it enables to build the culture and habitual attitude to deal with disaster or emergency situation.

\section{References}

Anderson, T., Curtis, A. and Wittig, C. (2014) 'Definition and Theory in Social Innovation Master of Arts in Social Innovation Danube University, Krems'.

Anies (2017) Negara Sejuta Bencana. Yogyakarta: Ar-Ruuzz Media.

BNPB, P. (2019) Trend Bencana 2013-2017, January, 23. Available at: https://bnpb.go.id/trend-bencana-20132017.

Ehrenreich, J. H. (2001) Coping with disasters - A Guidebook to Psychosocial Intervention. Revised Ed. Sharon McQuaide, M.S.W., Ph.D. Clinical Consultant. Available at: www.mhwwb.org.

G. Flor, Alexander, H. C. (2018) Komunikasi Lingkungan, Penanganan Kasus-kasus Lingkungan Melalui Strategi Komunikasi. Jakarta: Prenamedia Group.

James W. Chesebro, D. E. B. (1996) Analyzing Media. New York: The Guildford Press.

Karokaro, A. (2014) Kearifan lokal selamatkan warga Simeulue dari amukan tsunami (bagian 1), Mongabay. Available at: www.mongabay.co.id/2014/12/20/kearifan-lokal-selamatkan-warga-simeulue-dari-amukantsunami-bagian-1/ (Accessed: 20 December 2014).

Lakoro, Rahmatsyam \& Sabana, S. (2017) 'Design of Education Media For Disaster As Awareness of Life Space In Disaster Area', in The 4th International Conference on Creative Industry.

Lakoro, R. et al. (2018) 'The Exploration Of Spoken Culture To Create Life-Space Awareness In Educational Media Design', in International Conference Of Art Technology And Humanities 2018. Bandung, pp. 385396.

Lunenfeld, P. (2003) 'The Design Cluster', in Laurel, B. (ed.) Design Research, Methods and Perspective. Massachusetts: The MIT Press. 